\title{
Covid-19 Prevention (Study of Covid-19 Protocol and Relationship of Wudhu)
}

\author{
Ahmad Saefulloh $^{1^{*}}$, Sari Famularsih ${ }^{2}$, Mellyarti Syarif ${ }^{3}$, \\ Teguh Adimarta ${ }^{4}$, Muhammad Irfan Helmy ${ }^{5}$ \\ ${ }^{1,3,4}$ Study Program of Pancasila and Citizenship Education, \\ Faculty of Teacher Trainning And Education \\ Universitas Palangka Raya, Palangka Raya, Indonesia \\ Email: ahmadsaefulloh791@gmail.com \\ Email: syarifmellyarti@yahoo.com \\ Email: teguhadimarta@ahsanta@ac.id \\ ${ }^{2,5}$ Institut Agama Islam Negeri Salatiga, Indonesia \\ Email: sarifamularsih@yahoo.com \\ Email:mihelmy@iainsalatiga.ac.id
}

\begin{abstract}
Through the media of the time Efforts to prevent Covid-19 are currently closely related to the advice of Muslims against hygiene orders Various efforts are currently being made by all governments in the world in preventing and breaking the chain of distribution of co-19. Ranging from large-scale organizations namely international level such as WHO to small-scale organizations, namely in the family. All efforts made are inseparable from the sincerity of each individual who maintains that role. This article is motivated by the need to prevent the spread of Covid-19 from the viewpoint of the teachings of Islam. The purpose of this article is to study of covid-19 protocol policy and its relationship on internalization of wudhu' 'as an effort to prevent through the literature study method in the form of Government policies and various institutions that issue circulars related to the Covid-19 prevention protocol. The results of this study found that every policy or circular issued, entirely emphasizes and regulates clean and healthy lifestyles by always washing hands thoroughly. So, Wudhu' as a disciplinary activity for Muslims whose implementation is inseparable from washing hands. So this study is a form of emphasis on clean and healthy lifestyle in preventive efforts.
\end{abstract}

Keywords: prevention measures, Covid-19, policy, optimalization, wudhu

Paper type: Research paper

*Corresponding author: mihelmy@iainsalatiga.ac.id

Submited: 2020-06-16; Accepted: 2021-04-27; Published: 2021-04-29

Cite this document: Saefulloh, Ahmad, et al. (2021). Covid-19 Prevention (Study of Covid-19 Protocol and Relationship of Wudhu). The Journal of Society and Media, 5(1), 99-118. DOI: 10.26740/jsm.v5n1.p99-118 


\section{INTRODUCTION}

Through the media of the time the efforts made by the government to prevent the spread of the Covid-19 Virus at this time cannot be separated from the advice of Muslims to maintain cleanliness. Islam is very concerned about human cleanliness of all things in every activity that is carried out every day. The advice to do clean activities is carried out from starting the activity to ending the activity, for example, the Fajr prayer activity for Muslims begins with ablution when just waking up, namely cleaning some of the body parts, including organs that need to be guarded and protected during the Covid-19 pandemic. these are the face and palms. Likewise, when ending an activity it is recommended to perform ablution before bedtime as recommended by the Prophet Muhammad. Such is the importance of maintaining cleanliness so that the Prophet's hadith states that cleanliness is a characteristic of believers and one of the cleanliness that is often repeated in daily activities is ablution.

Seeing the condition of the nation and the world lately today, the corona virus pandemic still has a dangerous impact on humans, the number of victims continues to grow (Hasbi and Mamat 2020). Not only in Indonesia but even in the world, so various governments around the world make policies to remain at home, keep their distance and use personal protective equipment to prevent covid-19 transmission (Zaied 2017). The impact of the corona virus is felt in almost all sectors, such as the economic, social, cultural, education, transportation, agriculture, trade and other sectors. But the big impact is felt on the economic sector (Yunus and Rezki 2020). The world community feels economic hardship due to the corona virus, for example, many shopping centers are closed, factories are closed because they do not get raw materials, and people's income tends to decrease even get termination of employment (Siddiqui et al. 2020). In addition to the economic sector, it is also in the education sector, where the government must rack its brains hard in facing online learning in order to carry out co-handling 19 (Yang and Duan 2020).

The number of countries that have confirmed positive cases of Covid-19 until Thursday (3/26/2020) there are 174 countries with a total of 471,407 recorded cases, 114,051 patients recovered, and 21,287 people died (2.2\%) (BBC 2020). While in Indonesia alone there were 790 positive people, 31 people recovered and 58 people died recorded on Thursday (3/26/2020). The number of 
these cases is calculated from 17 November 2019 to 26 March 2020 (4 months) (Wikipedia, 2019-20 pandemic coronavirus, 2020) (Riou and Althaus 2020). This means that the increase in cases caused by covid-19 is relatively fast, because it exceeds the number of SARS sufferers in 2002 then in the same time frame (Mufida 2020).

The rapid spread of the Covid-19 outbreak invited serious attention by various parties, ranging from the world health agency, the domestic health agency, the president, the police, the Indonesian Ulema Council, the ministries, the Governor, the Indonesian Mosque Council (DMI), to various education units from basic to to the level of higher education makes policy rules in efforts to prevent the spread of Covid-19. Various prevention efforts that are currently being carried out are in order to break the chain of the spread of the virus so as not to spread widely and spread to others. These rules lead to discipline of personal hygiene and a reduction in the form of interaction between people. Personal hygiene especially on the palms and face becomes an important part that needs to be maintained (Nor Haliza Johari et al. 2013). So that the reduction as well as limitation of social interaction in order to maintain personal hygiene is to protect the area where the entry gap Covid-19 in the face, especially the nose, eyes and mouth.

Various circulars that are preventive protocols contain appeals for the application of healthy and clean living behaviors, one of which is through washing hands with soap and running water accompanied by disinfectant liquid, the aim is that dirt (including viruses) can be cleaned through the application of that behavior.

Indirectly in Islam also ordered to maintain the importance of cleanliness at all times, in addition to cleanliness as a form of healthy living behavior but also as a feature of the faithful (Suratkon, Chan, and Tuan Ab Rahman 2014). So, one of the efforts in the teachings of Islam itself so that humans always maintain healthy living behavior is by washing hands, washing the nostrils, washing the face, and ears contained in the Wudhu' movement (N. H. Johari et al. 2013).

The novelty of this article was written with the aim of analyzing government policies related to efforts to prevent Covid-19, one of the government efforts is to synchronize with religious teachings in preventing the spread of the Covid-19 outbreak through ablution 'as a clean living behavior, so it is important 
for Muslims in particular and society the world in general knows that ablution has a role in preventing the transmission of the corona virus.

\section{METHOD}

This article examines government policies regarding the Covid-19 Protocol and relates it to the Prophet Muhammad's advice to Muslims to maintain ablution as part of an effort to prevent the spread of the corona virus indirectly through optimizing the wudhu movement 'on the face and hands because this part is often ignored. when doing ablution because of gargling, cleaning the nose and ears is considered sunnah. This research uses literature review methods related to government policies, then in-depth analysis with a case study approach through strengthening the legal basis for Muslims. The object of research in this article is government and MUI policies related to the Covid-19 protocol which is the main instrument in research. Then a study is carried out on its relation to the sources of Islamic law, namely the recommendation of ablution 'at the beginning and end of Muslim activities. The purpose of this literature review methodology through a case study approach can generate policies from the MUI regarding the optimization of ablution 'in an effort to prevent the corona virus.

\section{RESULTS AND DISCUSSION}

Through wudhu', Muslims have indirectly and unconsciously prevented the spread of the corona virus, it is just that the quality of the recommended Wudhu' needs to be improved (Anon 2011). Namely optimizing the parts of the Wudhu' members on the face and palms because in that part there are Wudhu' sunnahs which are often ignored (Irmak 2014).This research will look at how the policies that have been established by the Government are related to the advice of Islam. So this paper seeks to analyze and map which policies include recommendations for clean and healthy living habits, especially those related to cleaning the face and washing hands.So we need to know in advance the characteristics of the corona virus, the mechanism of transmission through the parts of the face and palms, and how to protect and protect these important parts through the covid protocol policy and the recommendation for Wudhu'.

Characteristics of Covid-19 and Early Appearance. Corona Virus or known as Corona Virus Deases 2019 which is popularly known as Covid-19 is a 
collection of viruses from the Orthocoronavirinae subfamily in the Coronaviridae family, and the order Nidovarales is a group of viruses that can cause disease in birds and mammals (including humans). In humans themselves, covid-19 can cause respiratory infections starting with symptoms of colds, fever, dry throat, cough, to shortness of breath (Wikipedia, Coronavirus, 2020). Coronavirus is a enveloped virus characterized by a single stranded plus RNA genome in the form of symmetrical helices. The name coronavirus comes from the Latin "corona" which means crown (in the form of the appearance of virus particles) because of its shape like a crown or corona of the sun. This virus was discovered in the 1960s, with the name infectious bronchitis virus (in chickens) and two viruses from the human nasal cavity (starting from the common cold) so they are called human coronavirus 229E and OC43. Since then, other types of viruses have been identified so that in 2003 SARS-cov, HcoV NL63 (2004), Mers CoV (2005), 2012-nCoV (2012) and 2019-nCoV (2019) all of these viruses were associated with serious respiratory infections. Transmission of this virus, especially in humans by direct contact in close proximity and splashes or small droplets from the respiratory tract of the patient when sneezing and coughing (CDC 2020). The following are 7 groups / strains of human coronavirus that are currently known:

1. Human coronavirus 229E (HCoV-229E)

2. Human coronavirus OC43 (HCoV-OC43)

3. Severe acute acute respiratory coronavirus (SARS-CoV)

4. Human coronavirus NL63 (HCoV-NL63, New Haven coronavirus)

5. Human coronavirus HKU1

6. Coronavirus related to Middle Eastern respiratory syndrome (MERS-CoV), previously known as 2012 coronavirus novel and HCoV-EMC

7. Severe acute acute respiratory coronavirus 2 (SARS-CoV-2), formerly known as 2019-nCoV or "novel coronavirus 2019"

Some of them, namely Coronavirus HCoV-229E, -NL63, -OC43, and HKU1 continue to circulate in human populations and cause respiratory infections in adults and children throughout the world (Corman et al. 2018).

Related to the length of covid-19 survive in droplets (sneezing splashes) that stick to the surface of human skin, especially in the throat, nose and mouth, a 
study from Vincent J Munster and Neeltje van Doremalen published in "The new England Journal of Medicine" states that the virus It can last up to 3 hours after being released into the air, the droplet itself is fine between 1-5 micrometers - 30 times smaller than the size of a human hair (Munster et al. 2020). This means, the virus can be cleaned every less than 3 hours through a clean and healthy way of life.

Prevention Efforts in Countries with the Highest Category. Various efforts are currently being carried out by governments around the world in preventing the spread of covid-19. As a reference protocol for prevention of the world health organization issued signs as prevention efforts covid-19 as follows:

1) Avoid eating raw meat and eggs

2) Avoid smoking or smoking areas

3) Take medication as soon as symptoms appear and don't let the condition get worse

4) Wash hands after sneezing or coughing

5) Close your mouth before coughing or sneezing

6) If you believe you have been infected, avoid close contact with people

7) Take proper breaks

8) Stay away from the crowd

9) Clean your hands with soap and water or hand rub containing alcohol

10) Cover nose and mouth when coughing and sneezing with a tissue or elbow

11) Avoid making contact with anyone who has the flu, fever or other flu symptoms

12) Cook meat and eggs until cooked

13) Wear protection when in contact with wild animals or animals that are farmed or maintained (Hageman 2020).

Based on the prevention protocol above, the following countries issue preventive instructions by adjusting the conditions of their respective countries. For example in China the efforts made by the government to isolate the city of Wuhan, send special officers, and close access in and out of people to the area, established the Leading Group to manage the covid-19 epidemic and instructed citizens to use digital applications such as WeChat and integrated applications identify the health of citizens reported every day to find out the development of 
the condition of the population (Tian et al. 2020). Austria by banning access to train from Italy, Korea by using an application called "Corona 100M", an application on smartphones that warns users if they enter the area of patients infected with covid-19 within a radius of 100 meters. Japan by not holding all the activities that gather a lot of people and cancel the event, doing office work at home, the prohibition of entry for people who have visited China, and identifying passengers who cough and have fever when in town. Singapore by rational and transparent approach to its citizens. All efforts made refer to the protocol standards set by the world health organization, it's just that each country has specific ways of setting policies (daughter, 2020).

Prevention Efforts in Indonesia. Likewise in the State of Indonesia since the presence of Indonesian citizens who were tested positive for Covid-19 the government issued a policy in prevention efforts. Quoted from kompas.com (Azanella 2020) there are at least 4 government efforts in preventing the spread of covid-19, first to do the Thermo Scanner which is a tool used to determine a person's body temperature level that is installed at various international airports in Indonesia, the aim is that officers can find out what causes a person's high body temperature. Second, the no-fly instruction to Wuhan city in accordance with instructions issued by the Beijing Notam Office itself. Third, evacuate Indonesian citizens who are in crisis areas, especially in the area around Wuhan. Fourth, the health ministry activated 21 evacuation capsules at several international airports as a means of anticipating the spread of the virus that might be attached to incoming passengers.

In compiling information on the latest developments from the spread of Covid-19, the Indonesian government established a Task Force to deal with the acceleration of covid-19 prevention. The Indonesian government appoints Achmad Yurianto as a spokesperson who at all times updates the latest information on the transmission of this disease, this information includes developments related to patients who are positive, dead, and recovered. One of the innovations made in handling this is to oversee the mobility of the population in the area of each district / city that has formed a task force. Supervision carried out in this case is the key in controlling the outbreak, so it requires consistency and seriousness seriously in order to break the chain of spread of Covid-19. In several 
press meetings conducted, that the call to avoid crowds and wash hands as often as possible is inseparable from the message conveyed. The pattern of hand washing that is a major factor in the spread is often ignored because it has not become a habit.

In addition to the above efforts, various health protocols were also issued from various agencies such as Presidential Decree, Indonesian National Police, Ministry of Health, Ministry of Home Affairs, Ministry of Education and Culture, Ministry of Religion, and other ministries related to co-19 prevention efforts related to technical guidelines for implementing those efforts.

Of the various technical efforts made in prevention, all of these efforts can not be separated from the application of clean and healthy lifestyle behavior in a disciplined manner. Among the technical guidelines related to these efforts are:

1) Chief of Police Declaration number: Mak / 2 / III / 2020 regarding compliance with Government policies in handling the spread of corona virus (covid-19)

2) Ministry of Health, SE HK.02.01 / MENKES / 202/2020, Point 3 article f about what needs to be done during self-isolation, and point 5 article a about preventive measures. Point 3 article f "Apply clean and healthy living behaviors (PHBS) by consuming nutritious food, doing routine hand hygiene, washing hands with soap and running water and drying, doing ethics coughing / sneezing". Point 5 article a "Wash hands with soap and running water or hand sanitizer"

3) Muhammadiyah Central Executive Board Decree Number 02 / MLM / 1.0 / H / 2020 concerning Corona Virus Disease 2019 (covid-19) point 5, that Muhammadiyah members should improve their healthy lifestyle habits by maintaining personal hygiene and the environment and following prevention protocols covid-19 issued by the government.

4) Circular of Ministry of Education and Culture number 2 and number 2020 on prevention of co-19 in education units, which contains appeals to heads of provincial and district / city education offices, heads of higher education service institutions, leaders of higher education institutions, principals throughout Indonesia to take steps to prevent the spread of covid-19 in the education unit environment, so that schools ensure the availability of facilities for washing hands with soap (CTPS) and implementing clean and healthy living behaviors (PHBS). 
Saefulloh: Covid-19 Prevention (Study of

Covid-19 Protocol and Relationship of

Wudhu )

5) Chief of Police Telegram Letter number: ST / 868 / III / KEP / 2020 concerning efforts to anticipate the corona covid-19 virus that incorrectly contained the appeal ordered that hand sanitizers be provided in each room and members of the national police must wash their hands regularly.

6) Decree of the Head of the National Disaster Management Agency Number 9 A Year 2020 concerning Determination of the Status of Specific Emergency Disasters of the Corona Virus Disease in Indonesia.

7) Circular of the Director General of Islamic Education Number 285.1 of 2020 concerning efforts to prevent the spread of the covid-19 virus point 6 states that for boarding-based madsarsah to take steps to prevent the spread of covid19 by educating students / students to wash hands with soap clean the dormitory environment, roll up the mosque / mushalla carpet, and follow the protocol established by the government.

8) Circular of the Minister of Administrative Reform and Bureaucratic Reform number 19 of 2020 concerning Adjustment of the Work System of State Civil Apparatuses in Preventing the Spread of Covid-19 in Government Agencies in point $\mathrm{D}$ article 3 concerning the application of cleanliness standards that the staff of civil servants in government agencies for take steps to prevent the spread of covid-19 within government agencies in accordance with the appeal submitted by the minister of health and to conduct cleaning / steriliation of the work environment of each government agency.

9) Circular of the Minister of Manpower number M / 3 / HK.04 / III / 2020 concerning the protection of workers stated that the need for preventive measures by carrying out clean and healthy living behavior by integrating in the $\mathrm{K} 3$ program.

10) Circular of Civil Service Agency of the Province of Jakarta Special Capital Region Number 12 / SE / 2020 concerning anticipation of the spread of corona virus or covid-19 to employees.

11) Adjustment of Employee Work System in Preventing the Distribution of Covid-19 in the Provincial Government of the Special Capital Region of Jakarta 
Based on some of the above circular letters, which the authors take as a representative of other policies governing efforts to prevent covid-19, the authors see that all of the policies listed above include clean and healthy living behaviors by prioritizing hand hygiene by washing the hands.

MUI Fatwa and DMI Appeal. Covid-19 in the Islamic view is included in the category of infectious diseases or epidemics of infectious diseases called Thaun. Facing tha'un, the Islamic ummah refers to the guidance of the Prophet Muhammad SAW, which means "The plague of Ta'un is a verse, a very painful sign of God's power inflicted upon the people of His servants, if you hear the news about the plague of Tha'un, then do not ever enter his area, if Tha'un happens to an area and you are there then do not you get out of it ". From this hadith Muslims take the principle as a guideline that it is forbidden for anyone to enter an area in which a contagious plague is occurring.

Guidance from the Prophet Muhammad was also carried out by the leadership of Medina in the 18th Hijri which at that time was led by Umar bin Khattab. "Indeed' Umar ibn al-Khaththab (may Allah be pleased with him) exited towards Sham. Until when he arrived at Sargh, he was met by the Amir troops namely Abu 'Ubaidah ibn al-Jarrah and his companions. They told him that the plague was plaguing the land of Sham. Ibn 'Abbas said:" Umar then said: "Call me to the early Muhajirin (who experienced the second prayer of the Qiblat, ie those who emigrated before the Qibla was moved to the Grand Mosque - Syam an-Nawawi)." He then consulted with them and informed them that the plague was sweeping Sham. They then differed in opinion. Some say: "You have gone out for one purpose and we do not consider it appropriate for you to return from it." Others said: "You brought a group, especially the Companions of the Messenger of Allah, we do not see it well for you to bring them into the plague." "Umar then said:" Please all of you move from my place. Then "Umar said:" Call me to the Ansar. " So I (Ibn 'Abbas) called them and he then consulted with them. It turned out that the Ansar differed in opinion as did the Muhajirin. 'Umar then said:" Please all of you move from my place. Then "Umar said:" Call me to the old Quraysh of Muhajir al-Fath (who migrated after moving the Qiblah and before Fathu Makkah). " So I (Ibn 'Abbas) called them. Apparently there was no difference of opinion among them, all of them suggested: "You should go back with the group and don't bring them into the plague. Umar then called on the 
group: "Really tomorrow I will drive home, so get ready you guys." Abu 'Ubaidah ibn al-Jarrah said:" Do you want to run away from the destiny of Allah? " 'Umar replied:" If only the one who said that was not you, O Abu 'Ubaidah. Yes, we ran from God's destiny to God's destiny too. Doesn't if you shepherd a camel and go down to a valley where there are two edges of the valley, one fertile and one barren, then when you are shepherding on the fertile edge means you are shepherding with God's decree? And also when you shepherd on the edge of a barren valley, you also shepherd with the destiny of God ?. Ibn 'Abbas said:" Abdurrahman ibn 'Auf then came, he did not attend the previous deliberations because there was a need. "Abdurrahman then said:" I have knowledge about this problem. I heard the Messenger of Allah (saw) saying: "If you hear there is an epidemic in one area, do not you come there. But if the plague strikes an area when you are already in the area, do not escape from it. Said Ibn 'Abbas:' Umar then worshiped Allah and then returned home. (Narrated by al-Bukhari)

The two events above are a reference for Muslims in an effort to deal with the co-19 epidemic by taking a stand so as not to visit the affected area. Therefore, in addition to the above policy, the Indonesian Ulema Council (MUI), which in this case has the authority to provide guidelines for Muslims to participate in creating signs to prevent outbreaks that occur in Indonesia

In addition to some of the government institutions mentioned above in an effort to prevent covid-19 by issuing circular letters, the Indonesian Ulema Council (MUI) also issued fatwas as a result of the Ulama deliberations in handling this important issue for the benefit of the community in terms of worship.

Some considerations of the MUI in setting Fatwa related to the implementation of Worship in the effort to prevent covid-19, MUI considers the following principles:

1) Must not endanger yourself and endanger others

2) Refusing mafsadah takes precedence over seeking benefit

3) Difficulties cause ease

4) Danger must be rejected

5) Mortality must be prevented within the limits that are possible

6) Kemudharatan is limited according to levels 
7) The policy of the leader (authority holder) towards the people must follow the benefit

The above principle becomes the basis for the determination of the Fatwa for the Ulema Council in Indonesia, so that the health protocol to be determined does not violate the rules of implementing Muslim worship, of course. The above rules have been approved by the scholars involved in the determination of the fatwa, so the policy that governs the worship of Muslims in the atmosphere of Covid-19 was born. The following is an MUI fatwa related to the co-19 deployment prevention protocol:

1) MUI Fatwa number: 14 of 2020 concerning Organizing of Worship in Situation of the Covid-19 Outbreak in article 3 point $b$ states that "in the event that he is in an area where the potential for transmission is low based on the provisions of the authorities, he is still obliged to carry out religious obligations. as usual and obliged to protect themselves from exposure to covid-19, such as not having direct physical contact (shaking hands, hugging, kissing hands), bringing their own prayer rugs, and often washing their hands with soap ".

2) Appeal of DMI (Indonesian Mosque Council) number 041 / PP-DMI / A / II / 2020 concerning the Alert Prayer for Mosque / Mushalla addressed to all ranks of Regional, Regional, Subdistrict and Branch Offices of the Indonesian Mosque Council point 3 in order to always maintain cleanliness Wudhu' place and toilet with disinfectant liquid.

Based on the two appeals above, the authors see that every appeal there is an order for clean and healthy living behavior by washing hands, even in the DMI appeals including Wudhu' places' also recommended to be cleaned regularly.

Internalizing Wudhu in an Islamic perspective as an effort to prevent Covid-19. All forms of prevention efforts above also have to do with the suggestion of Islam in preventing the spread of co-19, namely through Wudhu' activities. Wudhu' 'for Muslims is one of the legal requirements before praying, whether it is obligatory prayer or sunnah prayer. In the Islamic Muslim holy book, the Koran surah al-maidah verse 6 Allah SWT says "O you who believe, if you want to pray, then wash your face and your hands to the elbows, and sweep your head and (wash) ) your feet are up to your ankles, and if you are junub then take a 
shower ... ". This verse is a direct command of Islam for Muslims to perform Wudhu' as a prerequisite for carrying out the prayer. Wudhu 'for Muslims is done at least five times a day, of course, following the prayer schedule that has been set in each region, except in certain circumstances and conditions then Wudhu' can be replaced with tayammum.

Wudhu' in some studies is used as a healthy lifestyle based on the commands of the Holy Qur'an, that the correlation of healthy lifestyle with quality of life can be done by maintaining cleanliness, one of them by getting used to Wudhu' (M. Nur Wahyudi 2015). Some other benefits of wudhu' such as can improve sleep quality (Dwi Lestari and Rofiqul Minan 2018), reduce stress levels in the elderly through hydrotherapy (Sari and Mahardyka 2017), reduce asthma symptoms (tiredness in the eyes due to being forced to see the computer for a long time) (Mukhaiminah, Mallapiang, and Habo Abbas 2019), support the achievement of spiritual intelligence in the elderly (Rahmawati, Qolbi, and Khotimah 2019), as therapy in rehabilitation of narcotics addicts (Saefulloh 2018), as well as one of the efforts to therapy a healthy life (M. Nur Wahyudi 2015). Likewise in efforts to prevent covid-19 Wudhu' has a major role for Muslims in particular.

In the implementation of Wudhu' 'for Muslims must pay attention to what the values of worship they contain, because every worship performed has a positive impact both physically and spiritually. Relating to clean and healthy living behavior, the integration of the value of education in Wudhu' as a co-19 prevention effort is as follows:

1. Wudhu"' is done through the selection of the right water, which is really holy water and purify it for its use. In addition, the implementation is also by flowing water to the determined limbs. So the water that is classified into this water is rain water, ice water, sea water, river water, well water and other types of water that have not been used or mixed with dirt.

2. Wudhu" is done by starting a sure intention, belief is the source of suggestions for the body. Good faith will make the body condition to be good, and vice versa. So, the intention of Wudhu' must be based on the belief to clean the hadats (impure physical causes) in accordance with the correct order of implementation. 
3. After the intention is sure, then done in the following order:

(a) Washing hands (rubbing and interrupting fingers), this makes all the dirt on the surfaces of the palms and back of the hands clean and before rubbing the other limbs, it is certain that the palms have been cleaned first, eliminating the worry of rubbing the parts other body surface parts.

(b) Gargling is part of the Sunnah of Wudhu' which has great benefits. Gargling means cleaning the oral cavity from disease transmission. The rest of the food often settles or gets stuck between the teeth, which if not cleaned (by rinsing or brushing your teeth) will eventually become a mediating germ growth. Gargling properly and doing it five times a day means that we can unknowingly prevent dental and mouth infections. Modern research shows that gargling can keep the mouth and throat from inflammation and keep the gums from sores. Gargling can also protect and clean teeth by removing food debris between the teeth after eating. Other benefits of gargling are also important to strengthen some of the facial muscles and maintain freshness. Gargling is an important exercise that is recognized by experts in the field of sports, because gargling if done by moving facial muscles properly can make a person's soul calm. Likewise, if there is a corona virus attached to the mouth, it will gush out along with the gargling water released. So if this is done routinely, it will minimize the attachment of viruses and other bacteria in the mouth because the mouth as one part of the respiratory tract into which bacteria and viruses enter the opening, so if rarely cleaned will be one of the main causes of covid-19 outbreaks.

(c) Cleaning the nostrils or Istinsyaq, means inhaling water with the nostrils, through the nasal cavity to the throat of the nose (nasopharynx). Its function is to clean the nasal membranes and mucus that is polluted by dirty air and germs. Nasal mucous membranes and is the first basis of respiratory defense. Through istinsyaq bacteria acute respiratory infections (ARI) can be prevented. Modern science research carried out by the University of Alexandria's medical team proves that most people who perform wudoo continuously, then their noses are clean and free of dust, bacteria and microbes. There is no doubt that the nostrils are susceptible to microbes and viruses, but by washing the nose continuously and doing 
istinsyaq (entering and removing water to and from the nose during Wudhu'), the nostrils become clean and free from inflammation and bacteria, and this reflects overall body health. This process can protect humans from the danger of transferring microbes from the nose to other limbs The nose is also part of the respiratory tract which is a gap for virus entry. Nostrils that are rarely cleaned are one of the biggest contributing factors other than through the mouth which is a gap for the virus to enter the respiratory tract. So, in Wudhu' 'is taught to always clean the nostrils by breathing water, then slammed. If cleaning the nostrils is often done, then at least minimize the possibility that the virus can stick to the nose and prevent the entry of the virus in the respiratory tract.

(d) Washing the hands up to the elbows, this is a part that must be done in Wudhu' 'and must be cleaned starting from the palm of the hand, the back of the hand, the gap in the fingers, to the elbow including the fold of the skin at the bottom of the elbow. Washing the hands up to the elbows can eliminate sweat and skin surface and clean the skin from fat partitioned by the skin glands, and this is usually the ideal place for breeding of bacteria. repeat. Such is the importance of washing hands on wudoo 'for Muslims, so that if this is routinely applied in the right way it will reduce the impact of the spread of viruses and bacteria on human body parts.

(e) Wiping some of the head, this part must also be done in Wudhu'. The head that is rubbed there are several ways that can be done, it can be on the front of the hair (above the crown), also can reach the tip of the head. Both of these methods are carried out by the scholars in accordance with the school that is followed, so if rubbing the head is often done can clean some of the head affected by bacteria and dirt.

(f) Wiping both ears, is part of the sunnah in the practice of Wudhu' which is done after rubbing part of the head. Cracks in the ear that are difficult to reach by water when someone is bathing unless rubbed with the fingers of the hand is one part of the body's organs that need to be washed when wudoo '. How to wash it done by massaging the outside and inside the ear using the thumb and index finger. In addition to being beneficial for ear hygiene, it also has an impact on other organs because the earlobe is also a 
nerve center which, if done properly, can nourish the body's nerves that are related, such as nerves on the head and abdominal organs.

(g) Washing both feet to ankles, is a mandatory part of Wudhu' 'which must be exposed to water. How to wash the feet is done by interrupting the toes so that water from the sole of the foot to the instep. If this is done often, dirt or bacteria that stick to the surface of the feet will be easily cleaned every time performing Wudhu' '. Washing the feet is also a part of PHBS that is needed to be done every time you enter the house to keep the house clean.

4. Wudhu' 'is carried out in an orderly manner, i.e. sequential steps according to the rules above, and emphasized to widen the scope of washing in the face, arms and legs.

5. Wudhu' movements' banned up to 3 repetitions on each movement, this is to ensure cleanliness that is done on every movement. This three-time repeating suggestion is part of the representation of the prevention of bacteria or viruses that are attached to the parts of the Wudhu'. So if a Muslim performs Wudhu' 'as often as possible outside of the obligatory prayer alone will only increase one's endurance in the face of covid-19

The steps above Wudhu' is a unit that needs to be carried out in the process of Wudhu', the steps above are combined between fardhu wudoo 'and sunnah wudoo', so to get the benefits that many should combine the two.At each step of Wudhu' 'above, is part of PHBS through the process and procedures for washing and cleaning properly, if in PHBS is according to WHO rules, then in Wudhu" is according to the rules of religious teachings.

As Muslims, the implementation of Wudhu' has to do with research by Vincent J Munster and Neeltje van Doremalen published in "The New England Journal of Medicine" states that the virus can last up to 3 hours after being released into the air. Muslims do the obligatory prayer five times a day, and Wudhu' is the main requirement that is done before praying. Then, at least 5 times will be performed Wudhu' every day. While the time for performing prayers ranges from 3 hours (zuhr to asr), 3 hours (asr to maghrib), 1 hour (maghrib to isya), 8.5 hours (isya to dawn) and the rest is the time span of entry of dawn to zuhr. This shows that the time span of the three prayers above is zuhr, asr, 
maghrib, to evening is around 3 hours, and this time is the time where people are active during the day. Whereas the time span from evening to dawn is the time at which Muslims rest at night. If during the daytime routine Wudhu' is done 'then this is an effort to prevent covid-19. Furthermore PHBS efforts are also made in the time span between the dawn prayer to the midday prayer. However, at least through religious advice, co-19 prevention efforts can increase human awareness, especially Muslims.

\section{CONCLUSION}

The conclusion of the above research is that wudhu 'is one of the PHBS (clean and healthy living behaviors) that is always applied by Muslims throughout the world. If Muslims at least perform Wudhu' 5 times a day, which is when performing the obligatory prayers, then at least PHBS has been applied as much as 5 times so that within the span of time the attachment of the virus that is transmitted through droplets from the human respiratory tract will be eliminated through the Wudhu' 'routine, especially if wudhu 'is performed not only on the obligatory prayers, but at every time and every time performing the sunnah prayers then surely the number of Wudhu's' will be increased. This research is motivated by research from Vincent $\mathbf{J}$ Munster and Neeltje van Doremalen which states that the virus can last for 3 to 4 hours in the air, then through Wudhu', 'which is also carried out within a span of 3 hours can kill the virus that attaches to human limbs, especially in the face of someone who is a gap in the entry of Covid-19 in the body. So, the government's efforts to prevent the corona virus through controlling hygiene activities on the face and palms are closely related to the orders of Muslims to maintain cleanliness. Through Wudhu' 'Muslims have tried to prevent the spread of the corona virus indirectly and unconsciously, prevention efforts have been carried out since starting activities in the morning, starting with the Fajr prayer which requires Wudhu', and ending its activities with Wudhu' before bed. So that the recommendation to perform ablution more frequently can become a recommendation by MUI for Muslims in preventing the corona virus as outlined in the MUI Declaration or other covid-19 prevention policy protocols. 


\section{REFERENCES}

Anon. 2011. "Ablution Wisdom in the View of Quran, Hadith, and Medicine." Arak Medical University Journal.

Azanella, Luftia Ayu. 2020. "4 Upaya Pemerintah Indonesia Cegah Masuknya Virus Corona.” Kompas.Com.

BBC. 2020. "Virus Corona: Peta Dan Infografis Terkait Pasien Terinfeksi, Meninggal Dan Sembuh Di Indonesia Dan Dunia." $B B C$.

CDC. 2020. "Science Brief: SARS-CoV-2 and Potential Airborne Transmission."

Corman, Victor M., Doreen Muth, Daniela Niemeyer, and Christian Drosten. 2018. "Hosts and Sources of Endemic Human Coronaviruses." in Advances in Virus Research.

Dwi Lestari, Nina and Muhammad Rofiqul Minan. 2018. "Efektivitas Terapi Wudhu Menjelang Tidur Terhadap Kualitas Tidur Remaja." Mutiara Medika: Jurnal Kedokteran Dan Kesehatan.

Hageman, Joseph R. 2020. "The Coronavirus Disease 2019 (COVID-19)." Pediatric Annals.

Hasbi, Sarah Aliya Che and Sufian Mamat. 2020. "The Ergonomics of the Islamic Ablution: Exploring Considerations for the Elderly in the Mosque." Cultural Syndrome a Peer-Reviewed, International Open Access Journal 2(1).

Irmak, M. 2014. "Medical Aspects of Ablution and Prayer." Journal of Experimental and Integrative Medicine.

Johari, N. H., R. Anwar, O. H. Hassan, and M. F. Kamaruzaman. 2013. "Human Behaviours Influence Framework of the Ablution Tub Design." in BEIAC 2013 - 2013 IEEE Business Engineering and Industrial Applications Colloquium.

Johari, Nor Haliza, Oskar Hasdinor Hassan, Rusmadiah Anwar, and Muhamad Fairus Kamaruzaman. 2013. "A Behaviour Study on Ablution Ritual among Muslim in Malaysia." Procedia - Social and Behavioral Sciences.

M. Nur Wahyudi. 2015. "Pola Hidup Sehat Dalam Perspektif Al-Qur ' an." Skripsi.

Mufida, Ifa. 2020. "Mengambil Hikmah Dari Munculnya Virus Corona." Timesindonesia.Co.Id. 
Mukhaiminah, Ina, Fatmawaty Mallapiang, and Sci Hasriwiani Habo Abbas. 2019. "Pengaruh Air Wudhu Terhadap Computer Eyes Syndrome (Asthenopia) Pada Karyawan Rumah Sakit Islam Faisal Kota Makassar.” Jurnal Ilmiah Kesehatan Diagnosis.

Munster, Vincent J., Marion Koopmans, Neeltje van Doremalen, Debby van Riel, and Emmie de Wit. 2020. "A Novel Coronavirus Emerging in China - Key Questions for Impact Assessment.” New England Journal of Medicine.

Rahmawati, Lilik, Khofifatul Qolbi, and Khusnul Khotimah. 2019. "Spirituality Building Bagi Lansia: Pengalaman Pendampingan Pada Lansia Di Desa Kare Kecamatan Kare Kabupaten Madiun.” Al-Khidmat.

Riou, Julien and Christian L. Althaus. 2020. "Pattern of Early Human-to-Human Transmission of Wuhan 2019 Novel Coronavirus (2019-NCoV), December 2019 to January 2020." Euro Surveillance: Bulletin Europeen Sur Les Maladies Transmissibles = European Communicable Disease Bulletin.

Saefulloh, Ahmad. 2018. "Muhasabah Sebagai Upaya Rehabilitasi Eks-Pecandu Narkoba Di Yayasan Suci Hati Padang." Nidhomul Haq: Jurnal Manajemen Pendidikan Islam 3(1):44-56.

Sari, Dita Kurnia and Muhamad Wahyu Mahardyka. 2017. "Penerapan Wudhu Sebagai Hydro Therapy Terhadap Tingkat Stres Pada Lansia UPT PSLU Blitar Di Tulungagung.” Journal Of Nursing Practice 1(1).

Siddiqui, Ruqaiyyah, Mustafa Khamis, Taleb Ibrahim, and Naveed Ahmed Khan. 2020. "SARS-CoV-2: The Increasing Importance of Water Filtration against Highly Pathogenic Microbes." ACS Chemical Neuroscience 11(17).

Suratkon, Azeanita, Chee Ming Chan, and Tengku Syamimi Tuan Ab Rahman. 2014. "SmartWUDHU': Recycling Ablution Water for Sustainable Living in Malaysia." Journal of Sustainable Development.

Tian, Sijia, Nan Hu, Jing Lou, Kun Chen, Xuqin Kang, Zhenjun Xiang, Hui Chen, Dali Wang, Ning Liu, Dong Liu, Gang Chen, Yongliang Zhang, Dou Li, Jianren Li, Huixin Lian, Shengmei Niu, Luxi Zhang, and Jinjun Zhang. 2020. "Characteristics of COVID-19 Infection in Beijing." Journal of Infection.

Yang, H. Y. and G. C. Duan. 2020. "[Analysis on the Epidemic Factors for the Corona Virus Disease]." Zhonghua Yu Fang Yi Xue Za Zhi [Chinese Journal of Preventive Medicine]. 
118 | The Journal of Society and Media 5(1)

Yunus, Nur Rohim and Annissa Rezki. 2020. "Kebijakan Pemberlakuan Lock Down Sebagai Antisipasi Penyebaran Corona Virus Covid-19." SALAM: Jurnal Sosial Dan Budaya Syar-I.

Zaied, Roubi A. 2017. "Water Use and Time Analysis in Ablution from Taps." Applied Water Science 7(5). 